\author{
VII International Forum on Teacher Education
}

\title{
Character Education Competence of a Teacher in the Professional Life Cycle
}

\author{
Elena Yu. Ilaltdinova (a), Svetlana V. Frolova (b), Tatiana N. Sergeeva* (c) \\ (a), (b), (c) Minin Nizhny Novgorod State Pedagogical University, 603005, Nizhny Novgorod (Russia), 1 \\ Ulianova street,mininuniver@mininuniver.ru
}

\begin{abstract}
The modern educational environment is characterized by a number of global challenges and the emergence of a new paradigm of value orientations at the time of unlimited freedom of self-determination, multiculturalism, and multiple identity of the individual. All this escalate the problem of understanding the true, false and pseudo values. In the world of absolute uncertainty, instability, the importance of the character education competence of the teacher is increasing as the teacher is responsible for designing the students' educational environment. In today's reality the effective development of the character education competence of a teacher, which is not limited only to the period of studies at a teacher university, is of utmost importance. The authors consider the development track of the teacher's competence in character education throughout the entire professional life cycle in the regional socio-pedagogical cluster. Experimental research has confirmed the need to update the formation of character education competence both for the teaching staff of a teacher university, who are responsible for organizing the professional character education, and for the future teachers who will come to school tomorrow. The authors suggest that the character education competence of a teacher begins its formation long before entering the teaching profession and is determined by the axiological content of the quasi-professional communities in which an individual is involved.
\end{abstract}

Keywords: character education, character education competence, professional life cycle.

\section{(C) 2021 Elena Yu. Ilaltdinova, Svetlana V. Frolova, Tatiana N. Sergeeva}

This is an open access article distributed under the terms of the Creative Commons Attribution License (CC BY 4.0), which permits unrestricted use, distribution, and reproduction in any medium, provided the original author and source are credited.

Published by Kazan federal university and peer-reviewed under responsibility of IFTE-2021 (VII International Forum on Teacher Education)

\footnotetext{
* Corresponding author. E-mail: serge199@yandex.ru
} 


\section{Introduction}

Recent research on education focuses on the problems of how to organize character education in educational environments theoretically, methodologically and practically. We adhere to the definition of character education given in the Law on Education in the Russian Federation. It says, "character education is activities aimed at personality development, creating conditions for self-determination and socialization of students on the basis of social, cultural and moral values, rules and norms of behavior adopted in Russian society in the interests of a person, family, society and the state, the formation of a sense of patriotism, citizenship in students; respect for the memory of the country's defenders and heroes, law and order, a man of labor and the older generation, mutual respect, respect for the cultural heritage and traditions of the multinational people of the Russian Federation, nature and the environment".

We believe the recurrence of character education at schools is conditioned by the ongoing search for a fundamental basis of a civil society. Such society values belonging to the traditions of the Russian people. Moral values are realized in a sustainable model of positive social and ethical behavior. Civil society embodies national identity, shows national self-awareness and is capable of bearing conscious responsibility for themselves and society.

A number of crucial points in the modern sociocultural environments (Hösle, 1994) reveal the problem of the ways to implement character education starting from the conceptual methodological level and ending with the practical forms and methods of its implementation.

The first is that there is a significant shift in understanding the concept "normality" as the social norms have transformed dramatically. A new paradigm of values emerged including multicultural identity, nonbinary gender identity, a same-sex parented family and its perception in the modern world. It lays the foundation for new goals of character education and the nature of a person's growing up. Russia is perhaps the most archaic in this regard, but this does not refute the idea that all the key changes are already on the threshold of today.

The second critical point arising at the level of the state is the crisis of national identity. Who are we and where are we going? What is the basic maxim that embodies the national idea outside the political and religious context? What is the national idea meaningful in the personal context of an individual who identifies themselves as a Russian, living on the territory of the Russian Federation and being a Russian citizen? 
The third critical moment is the transformation of the educational relationship between student and teacher. The basic professional values of the teaching profession are uncertain, portrait characteristics and the system of professional and personal qualities of a teacher are blurred. All this brings volatility of a teacher's professional status and the nature of educational relations between teacher and student. The very axiological content of interaction in education is inconstant (Frolova \& Ilaltdinova, 2018). Changes in the sociocultural environments change not only educational reality but also the institutions that exist in it (Readings, 2010; Altbach, 2018; Barber, Donnelli, \& Rizvi, 2013; Thomas, 2020).

The modern school should be ready to face the challenges of the modern world. School is able to preserve, multiply and pass on to new generations the national socio-cultural heritage. It is the source of morality, responsibility, inner freedom and consciousness of every person. A teacher still plays an important role in this, hence the effective development of character education competence throughout the teacher's professional life cycle seems of utmost importance.

\section{Purpose and objectives of the study}

The purpose of the study is to comprehend the approaches and to outline conditions for the development of the character education competence of a teacher in the professional life cycle.

\section{Literature review}

It is a complicated and ambiguous issue to look for a methodological approach and conditions for the development of character education competence of a teacher. We witness reconsideration of the meanings of education in recent decades. The researchers seek means and methods of organizing the educational environment adequate to the new content of education.

The recurrence of character education as a transition from mass education to a new stage of its development is defined in different ways by different scholars. Some scholars (Gazman, 2002; Mikhailova \& Yusfin, 2001) define it as a transition to the pedagogy of "freedom". Quite a number of scholars (Asmolov, 1990; Grebenyuk \& Grebenyuk, 2000) proclaim the need for an individual approach to the student. Some (Bondarevskaya, 1997; Serikov, 1994; Yakimanskaya, 1996) consider it as the need for a personalityoriented approach in education, making the student the subject of the educational process. Bakhtin (2008) believes that the educational process should be based on establishing dialogue, support, cooperation, selfdevelopment, and continuous enhancement of its actors. Manuilov (2008) focuses on forming a character education environment. 
There is a surge of interest to the personality of the teacher alongside the issues of character education in pedagogical science: what should a teacher be like in the new world of education?

In the last decade psychology has also focused on issues of professionalism and professional competence of a teacher (Klimov, 2010; Markova, 2006). Serikov (2020), Shiyanov \& Kotova (2000) pay attention to the problem of personal development of future teachers.

A profound study on the problems of forming the character education competence of a teacher was carried out by Sorokoumova (2011). She defines the character education competence of a future teacher as an integrative personality structure that determines the teacher's ability to exert an educational influence on the personal development of a child at different stages of ontogenesis in accordance with the value-goal attitudes of modern society.

We note however, that studies devoted to the development of the character education competence of a teacher limit this process by the boundaries of teacher education. Basically, researchers consider that character education competence is formed during the period of study at the university.

Traditionally, the professional life cycle of a teacher is determined by the moment a future teacher enters a teacher training university. The teacher's professional life cycle includes several equally significant successive stages: entry into the profession, consolidation in the profession, maturity in the profession, exit from the profession. The aim of these stages is not only to provide schools with the best graduates, but also to retain them in the teaching profession, to motivate them to self-development, as well as to form a stable "teachers capital" of the country (Fedorov, Ilaltdinova \& Frolova, 2020).

However, the start of the teacher's professional life cycle begins long before entering the teacher training university. The professional self-determination of the individual gradually and intuitively takes place, based, among other things, on the past social experience. So the character education competence of a teacher starts to form long before entering the teaching profession. It is determined by the axiological content of the quasi-professional communities in which a future teacher is involved. The formation of the character education competence of a teacher begins with participation in summer children's camps, student self-government, workshops, sports training and interaction with teachers. All this launches the development of the character education competence of an individual.

\section{Methodology}


Theoretical and empirical research methods are applied in the study. The leading theoretical research method is the analysis of pedagogical, philosophical and psychological literature. Empirical research methods are polls and measurements of the axiology of interaction between a teacher and a student of a teacher training university, the social ecosystem of the university, the image of a modern teacher. A diagnostic examination of the educational environment of the university was carried out in 2018-2019 at Minin University. It had been developed by the authors of the article. Diagnostic examination included an assessment of the university's resources, internal positioning, the psychological climate in the educational environment, the nature of the interaction between students, university teaching staff and functional departments of the university (education quality center, library, e-learning center, etc.). The diagnostic examination took the form of a survey conducted among the teaching staff and university students. 1170 students and 124 teachers of Minin University took part in the survey.

\section{Results}

Based on the research, we define the character education competence of a teacher as an integrative unit of personal education, which is formed throughout the professional life cycle. It is the ability of an individual to successfully organize pedagogical interaction with other actors of education. The aim of such interaction is to form positive social models of behavior, exchange moral values and cultural meanings. It is based on the principle of the convention of generations and the representativeness of professional values expressed in the interaction.

The character education competence of the future teacher is determined by the social experience of the individual, which is formed throughout a person's life, starting from the period of childhood. During the period of a person's growing up and the formation of their worldview such aims and values of character education are formed which the teacher subsequently transmits to the pupils. Social activity of an individual in childhood and adolescence gives a person an idea of the process of organizing character education activities.

Teacher experience as a counselor, assistant, organizer of character educational events is of particular importance. Teacher experience of a future teacher can be organized through such activities as:

- Counselor practice in school camps, community practices;

- Patronage work / support / assistance in a one particular branch of the children's association or school government; 
- School mediation service;

- Volunteering;

- Social engineering.

The way a teaching profession is perceived by a person is definitely determined by interaction with one's own teachers. Positive examples of one's teachers form not only character education competence in future teachers, but also inspire them to devote their lives to the teaching profession.

The key areas of continuous effective development of character education competence are:

- establishing psychological and pedagogical classes (including virtual ones) at secondary schools,

- introduction of a model of identification, selection and support of pedagogically gifted youth,

- implementation of a new model of employer-sponsored teacher training,

- organization of a model of professional character education at the teacher training university,

- introduction of a mechanism of in-service supervision of a young teacher.

Three models of psychological and pedagogical classes within the network interaction "school - university" are currently worked out in the Nizhny Novgorod region. Firstly, a psychological and pedagogical class is based on in-depth study of psychology and pedagogy. Secondly, a psychological and pedagogical class is focused on meeting the need for the teaching staff at the municipal level. Thirdly, a psychological and pedagogical class stimulates students' professional self-determination and self-awareness. The applied models allow not only to train high school students in the field of psychology and pedagogy, but, first of all, to ensure the development of the character education competence of future teachers.

The development of character education competence continues in the structure of the regional sociopedagogical cluster (Fedorov, Ilaltdinova, Guseva, \& Frolova, 2020), which we define as a resource environment for professional development of a teacher. The elements of the regional socio-pedagogical cluster are:

- a number of educational institutions of the region that provide preschool, secondary, additional, special, and correctional education, 
- psychological and pedagogical classes in schools is the institution of the regional career guidance system, the reproduction of teaching staff in the region, increasing the level of character education competence in the region.

- student-teacher communities (subject-oriented or project-oriented) are the basis of forming and developing a regional career guidance system.

- clinical teaching practice,

- action research centers at schools,

- professional associations of teachers.

A specially organized character education environment at a teacher training university is considered important for the development of character education of a teacher. A number of experimental studies suggest the need for theoretical and practical environmental solutions in the organization of professional character education in a teacher training university. More than 1170 students took part in a comprehensive examination of the educational environment conducted by Minin University. It was organized before the pandemic, so it was face-to-face. The results of the study characterize the qualities of the social ecosystem of the teacher training university, the potential of the educational environment, assessment of the character education potential of the teacher training university's educational environment.

The image of a professor and their character education competence, which determines the nature of interaction with students, plays an important role in organizing professional education of a teacher. Analysis of the character education competencies of university teaching staff showed that $84.9 \%$ of students rate the professional activities of their teachers highly. Students note the importance of different professional and personal qualities among the positive qualities of teachers. They are: professionalism, the ability to deliver lectures in a clear way, a sense of humor, the ability to listen and understand the student.

The effects of the influence of teachers on students were considered. The results show that $23.2 \%$ of students experience a positive impact on their professional motivation, $18.1 \%$ - on the development of communication skills, $17.5 \%$ of students - on the students' ability to memorize difficult points. However, $11.3 \%$ of students experience losing the purpose and meaning of their education, and $10.3 \%$ of students do not feel any influence from teachers. Students lack teacher-student cooperation and note the need for it.

The study discovered a gap in the image of the teacher in student's and teacher's representation. 
The top qualities of a teacher according to the teacher training university staff are (in descending order): aspiration for professional development, competence, responsibility, intelligence development, creativity, motivation, striving for self-development, communication skills, knowledge of the subject, pedagogical tact. The necessary qualities of a teacher from the point of view of a teacher training university staff differ dramatically from the top qualities of a teacher in a global context. The qualities are reflected in the ethical codes of a teacher in different regions of the world. The qualities rated last by Russian teachers are empathy (№ 1 in the world (Frolova \& Ilaltdinova, 2018), love for children, moral and respect for an individual. These qualities are among the top qualities of a "universal" teacher. The study revealed the insufficient legal acts knowledge in the field of education, as well as the insufficient knowledge of forms and methods of education.

The study showed that the main goal of the educational process is defined by teachers as the knowledge achievement (56\%). $45 \%$ of teachers share the responsibility for achieving it together with students. $16 \%$ of teachers believe that the low cultural and intellectual level of students complicates the educational process greatly .

However, an important result for the methodology of professional education is that $23 \%$ of university teaching staff learn from students, $23 \%$ are inspired by students. Thus, we see that education, including character education of adults in the university environment is a generation convention process. It establishes effective intergenerational interaction between a teacher and a student in order to exchange values, meanings and knowledge.

The attitude of teachers to student participation in student communities and associations is mostly positive: positive $46 \%$ of teachers, rather positive than negative $-32 \%$, neutral - $13 \%$, rather negative than positive $23 \%$, negative $-3 \%$ of teachers.

Characterizing the student environment, among the top qualities of a student teachers rate first emotionality and enthusiasm, but, at the same time, rate second concentration on some minor issues. This indicates the heterogeneity and ambiguity of subject interaction in the educational environment. The ability to deliver lectures in a clear way ranks third. High requirements to the teacher testify to the fact that students have a clear view about the quality of education and the proper level of the educational process. Nervousness and hot temper rank fifth in students' qualities, which, most likely, is a characteristic psychological feature of student age. Exactingness and responsibility occupy the sixth and seventh position, which allows us to speak of the ability to share responsibility for the educational result. 
However, in 8th place is the disrespectful attitude of the student to the teacher, which is, possibly, a consequence of fluctuations in the social status of the university teacher. A sense of humor, the ability and desire to get involved in work, and the ability to put forward initiatives are the final positions in the top 10 qualities of students as a teacher university staff see it.

\section{Discussion}

The study revealed a number of key problems in the student-teacher interaction. One of the problems is the blurring of the character education component in the structure of the educational process. The notion of pedagogical ideal is somewhat vague. At the same time, the study illustrates that the teacher perceives the student as an actor of the educational environment, the student is an actor in education. This perception will let us determine the methodological basis for the professional education of the future teacher (Markova, Tsyplakova, Sedykh, Khizhnaya, \& Filatova, 2020). It should be based on the generations convention principle and is implemented through a network of sustainable student-teacher collaborations.

The structure of the regional socio-pedagogical cluster contributes to the launch and maintenance of the process of forming the character educational competence of the future teacher. Professional education at the teacher training university occupies only one of the stages of professional development in this process. The trend for dispersion of professional experience and knowledge in the socio-cultural environment is quite widely spread in teacher education. The teacher training university is not the only element in the sociocultural environment and is a place for professional development along with other social institutions.

\section{Conclusion}

The involvement of the future teacher in socially significant activity during the period of growing up, immersion in the pedagogical profession when studying at the psychological and pedagogical class, educational environment of the pedagogical university seem of utmost importance. Postgraduate support of the first years in profession, participation in the experimental sites and professional associations form cognitive, value-based emotional volitional components of educational competence, manifested in the acquisition of experience in educational activities.

The study revealed a number of new questions that constitute a prospect of further research. It seems perspective to find out in what way the success of a person's participation in quasi-professional environments depends on a person's career guidance choice in different periods of one's growing up. It is essential to determine and substantiate pedagogical conditions and the methodological basis for forming the character education competence of a teacher in the structure of the teacher's professional life cycle. 
Determining the necessary conditions for the development of character education competence of teachers in a multipolar world is becoming the key objective of modern education.

\section{References}

Altbach, Ph. G. (2018). Global perspectives of higher education. Moscow: Publishing House of the Higher School of Economics.

Asmolov, A. G. (1990). Psychology of the Individual. Moscow: MGU.

Bakhtin, M. M. (2008). To the methodology of the humanities. Personal development, 4.

Barber, M., Donnelli, K., \& Rizvi, S. (2013). An avalanche is coming. Higher education and the revolution ahead. Education Issues, 3, 152-236.

Bondarevskaya, E. V. (1997). Humanistic paradigm of student-centered education. Pedagogy, 4, 11-17.

Fedorov, A., Ilaltdinova, E., Guseva, L., \& Frolova, S. (2020). Convention of generations in the modern educational environment. Journal of Intergenerational Relationships, 1-19. doi: $10.1080 / 15350770.2020 .1791780$

Fedorov, A. A., Ilaltdinova, E. Yu., \& Frolova, S. V. (2020). Open pedagogical education of the future. Nizhny Novgorod, Moscow: Flinta.

Frolova, S. V., \& Ilaltdinova, E. Yu. (2018). The problem of ethical norms in the professional image of a teacher: a comparative analysis. Prospects for Science and Education, 3(33), 74-78.

Gazman, O. S. (2002). Non-classical education. From authoritarian pedagogy to pedagogy of freedom. Moscow: Miros.

Grebenyuk, O. S., \& Grebenyuk, T. B. (2000). Fundamentals of pedagogy of individuality: Textbook. Kaliningrad: Kaliningrad University.

Hösle, V. (1994). Crisis of individual and collective identity. Questions of philosophy, 10, 112-123.

Klimov, E. A. (2010). Psychology of professional identity. Moscow: Akademia Publishing House. 
Manuilov, Yu. S. (2008). Conceptual foundations of the environmental approach in education. Vestnik of N.A. Nekrasov Kostroma State University, 14(4), 21-27.

Markova, S. M., Tsyplakova, S. A., Sedykh, C. P., Khizhnaya, A. V., \& Filatova, O. N. (2020). Forecasting the Development of Professional Education. The 21st Century from the Positions of Modern Science: Intellectual, Digital and Innovative Aspects, 91, 252-259. doi: 10.1007/978-3-030-32015$7 \_51$

Markova, A. K. (2006). Psychology of professionalism. Moscow.

Mikhailova, N. N., \& Yusfin, S. M. (2001). Pedagogy of support. Moscow: Miros.

Readings, B. (2010). University in ruins. Moscow: Publishing House of the Higher School of Economics.

Serikov, V. V. (1994). Personal approach in education: concepts and technologies: a monograph. Volgograd: Change.

Serikov, V. V. (2020). Communicative Tools For Creating Personality-Developing Situations Within The Educational Process. In E. Tareva, T. N. Bokova (Eds.), European Proceedings of Social and Behavioural Sciences (pp. 891-900). Moscow: Moscow City University.

Shiyanov, E. N., \& Kotova, I. B. (2000). The development of personality in education. Moscow: Akademia.

Sorokoumova, G. V. (2011). Educational competence of the future teacher: psychological mechanisms and conditions for development (Unpublished doctoral dissertation). University of Russian Academy of Education, Nizhny Novgorod, Russia.

Thomas, M. (2020). Virtual Teaching in the Time of COVID-19: Rethinking Our WEIRD Pedagogical Commitments to Teacher Education. Frontiers in Education, 5, 1-11. doi:10.3389/feduc. 2020.595574

Yakimanskaya, I. S. (1996). Personality-oriented education in modern school. Moscow: September. 